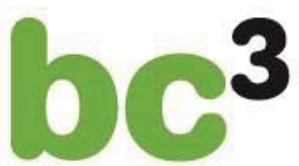

BASQUE CENTRE

FOR CLIMATE CHANGE

Klima Aldaketa Ikergai

\title{
Time and tide wait for no man:
}

pioneers and laggards in the deployment of CCS

Dirk Rübbelke and Stefan Vögele

September 2013

BC3 WORKING PAPER SERIES

2013-13 
The Basque Centre for Climate Change (BC3) is a Research Centre based in the Basque Country, which aims at contributing to long-term research on the causes and consequences of Climate Change in order to foster the creation of knowledge in this multidisciplinary science.

The $\mathrm{BC} 3$ promotes a highly-qualified team of researchers with the primary objective of achieving excellence in research, training and dissemination. The Scientific Plan of BC3 is led by the Scientific Director, Prof. Anil Markandya.

The core research avenues are:

- Adaptation to and the impacts of climate change

- Measures to mitigate the amount of climate change experienced

- International Dimensions of Climate Policy

- Developing and supporting research that informs climate policy in the Basque Country.

The BC3 Working Paper Series is available on the internet at

http://www.bc3research.org/lits_publications.html

Enquiries (Regarding the BC3 Working Paper Series):

Prof. Sérgio H. Faria

Email: sergio.faria@bc3research.org

www.bc3research.org

The opinions expressed in this working paper do not necessarily reflect the position of Basque Centre for Climate Change (BC3) as a whole.

Note: If printed, please remember to print on both sides. Also, perhaps try two pages on one side. 


\title{
Time and tide wait for no man: pioneers and laggards in the deployment of CCS
}

\author{
Dirk Rübbelke*a,b, Stefan Vögele ${ }^{\mathrm{c}}$
}

In Europe the ambitions of individual countries to deploy carbon capture and storage (CCS) technologies are diverse. Reasons for this are, amongst other things, the heterogeneity of national electricity generation systems and storage capacities and the differences in the public perception of these technologies. In this analysis we investigate the consequences of partial deployment of CCS, i.e. we consider a situation where some European countries (the "pioneers") actively deploy CCS technologies, while others (the "laggards") do not use CCS. Our study focuses on the question whether it pays throughout to be a pioneer and whether laggards will generally be disadvantaged. In our assessment, we take into account impacts on consumers affected from rising electricity prices, electricity suppliers whose profits are influenced by changes in both electricity prices and sales, and international trade-flow changes (modifications in European electricity import/export patterns).

Keywords: Carbon capture and storage (CCS); electricity generation; environmental technology; load dispatch approach

Cite as: Rübbelke, D. and S. Vögele (2013) Time and tide wait for no man: pioneers and laggards in the deployment of CCS. BC3 Working Paper Series 2013-13. Basque Centre for Climate Change (BC3). Bilbao, Spain.

\footnotetext{
*Corresponding Author. Email: email@email.com

${ }^{a}$ Basque Centre for Climate Change (BC3), 48008 Bilbao, Spain.

${ }^{\mathrm{b}}$ IKERBASQUE, Basque Foundation for Science, 48011 Bilbao, Spain.

c Institute for Energy and Climate Research - Systems Analysis and Technology Evaluation, Forschungszentrum Jülich, 52425 Jülich, Germany.
} 


\section{Introduction}

Carbon capture and storage (CCS) is frequently regarded as a potentially effective and important option to slow global temperature rise (see e.g. IEA 2011b, Luderer et al. 2012, Szulczewski et al. 2012). At the same time it allows for ongoing use of conventional fuels like coal (see EC 2013).

Some countries tend to act as leaders and others as laggards in adopting this technology. In this study, we categorize countries in terms of their prospective leader/pioneer or laggard roles concerning the deployment of a specific climate protection technology, i.e. CCS. ${ }^{1}$

As the deployment of CCS technology is still in its infancy, we have to build some expectations about individual countries' conduct in this respect. We do this by categorizing the EU-27 countries according to two criteria and those fulfilling all of them are considered as likely pioneers. In addition to the identified EU-27 pioneer countries, we suppose that non-EU country Norway will also become a leader in European CCS deployment as it has the largest storage capacity in Europe. Also public acceptance is high and R\&D CCS projects were already established in Norway.

The two requirements we postulate before we consider an EU-27 country as a pioneer are that 1) it has already implemented CCS R\&D projects, and 2) it has established a national CCS roadmap.

Then, having identified prospective pioneers and laggards, we consider two different European scenarios where the laggard countries postpone the large-scale deployment of CCS in their electricity sectors while the pioneers foster deployment. Based on these scenarios we identify the effects of CCS use on electricity prices in and electricity import and exports of individual European countries (both pioneers and laggards). We are furthermore interested in the potential effects of CCS deployment by pioneer countries on national production levels, wholesale prices (to some extent influencing electricity consumers' welfare) and producers' profits. ${ }^{2}$

In our analysis, we proceed as follows: In Section 2, we explain why we assign individual EU-27 countries the role of pioneers (the Netherlands, Poland, Romania and Great Britain) and why other European countries are supposed to behave like laggards in our analysis. In Section 3, we outline the framework of our model and in Section 4 we present the results of our analysis. Section 5 concludes.

\section{Pioneers and Laggards in the EU-27}

As there are no objective criteria for unambiguously assigning to a country the role of a prospective laggard or of a leader/pioneer, setting a distinctive borderline always has something of an ad hoc decision. We consider the EU-27 countries and choose the following two criteria that have to be fulfilled in order to consider a country as a pioneer: 1) it has already implemented CCS R\&D projects, and 2) it has established a national CCS roadmap. Stakeholder perception or public perception may be seen as an important piece of additional information which should be explored in future work. ${ }^{3}$. Criteria 1) and 2) can be easily checked for EU-27 countries and the results are presented in Table 1.

\footnotetext{
${ }^{1}$ Such distinctions between laggard and pioneer/leader countries is applied in diverse policy areas, e.g. in the context of international (Gupta 2010) or European climate policy (Hey 2010).

${ }^{2}$ There is a growing strand of literature on the incentives to adopt new technologies and the best timing; see, e.g. Requate (2005), van Soest (2005) and Perino and Requate (2012).

${ }^{3}$ A study by Shackley et al. (2007: 77, 2009: 351) finds relatively high public acceptance in the Netherlands, Great Britain and the group of Central and Eastern European Countries.
} 
Table 1: CCS in the EU-27

\begin{tabular}{|l|c|c|}
\hline Country & $\begin{array}{c}\text { R\&D } \\
\text { Projects }\end{array}$ & $\begin{array}{c}\text { CCS } \\
\text { Roadmap }\end{array}$ \\
\hline The Netherlands & yes & yes \\
\hline Poland & yes & yes \\
\hline Romania & yes & yes \\
\hline Great Britain & yes & yes \\
\hline $\begin{array}{l}\text { Bulgaria, Czech Republic, Denmark, Finland, } \\
\text { France, Germany, Italy, Portugal, Spain, } \\
\text { Sweden }\end{array}$ & yes & no \\
\hline $\begin{array}{l}\text { Greece, Hungary } \\
\text { Austria, Belgium, Cyprus, Estonia, Ireland, } \\
\text { Slovia, Lithuania, Luxembourg, Malta, }\end{array}$ & no & nes \\
\hline
\end{tabular}

Sources: Bellona Environmental CCS Team (2012a)

As can be observed from Table 1, only four of the displayed EU-27 countries have passed both 'pioneer'-criteria, i.e. Poland, Great Britain, The Netherlands and Romania.

Poland's electricity consumption is rather carbon intensive as 90 percent of its electricity generation is fueled by coal which is the second-highest share of coal in the total fuel mix for electricity generation of a country worldwide. ${ }^{4}$ Poland's economy is among the least carbon-efficient in the EU (World Bank 2011). ${ }^{5}$ CCS is seen - besides end-use efficiency improvements and renewable energy use as one of the most important options to reduce $\mathrm{CO}_{2}$ emissions in Poland (OECD/IEA 2010). However, the carbon storage capacity in Poland is according to a conservative estimate by Vangkilde-Pedersen, Allier, Anghel et al. (2009) only $2.94 \mathrm{Gt}$, and according to Höller and Viebahn (2011: 4903), the $\mathrm{CO}_{2}$ emissions from large point sources in the next 40 years will be about 2.5 times as high as the conservative estimates of storage capacity. In contrast, other studies found much higher levels of storage capacity (see Bellona Environmental CCS Team 2011: 25-26) as estimates are subject to high uncertainty. Depending on the actual domestic storage capacity, foreign capacity for CCS might be needed in order to exploit CCS as a major tool for $\mathrm{CO}_{2}$ abatement in Poland.

The situation is reverse in the UK, where there is abundant carbon storage capacity, ${ }^{6}$ which is 1.5 times as high as the $\mathrm{CO}_{2}$ emissions from British large point sources in the next 40 years (Höller and Viebahn 2011: 4903). The UK, the seventh largest coal importer in the world (33 Mt in 2011), has a share of coal in the electricity fuel mix of only 29.2 percent (1 April 2011 - 31 March 2012; data from DECC 2012b). According to DECC (2012a), CCS can be regarded as "a major green growth opportunity for the UK" (p. 6) and it is anticipated that around 90 percent of the $\mathrm{CO}_{2}$ emitted from large point sources in power generation and industrial sectors "could be captured and safely stored" (p. 13). Thus, like in the case of Poland, there are ambitions to pursue the CCS strategy intensively.

The conservative estimate of total effective storage capacity in the Netherlands is according to Höller and Viebahn (2011: 4901) about $3 \mathrm{Gt} \mathrm{CO}_{2}$ and thus does not cover Dutch 40-years emissions from

\footnotetext{
${ }^{4}$ In its neighboring country Germany it is only 44 percent, for example.

5 At the same time Poland is ranked $9^{\text {th }}$ among the largest coal producers worldwide in 2011 (World Coal Association 2012) which implies that Poland has a strong interest in the deployment of technologies allowing for a 'clean' use of coal as it might help to ensure demand for its coal exports.

${ }^{6} 14.4 \mathrm{Gt}$ is the conservative estimate of storage capacity in the UK (Vangkilde-Pedersen, Allier, Anghel et al. 2009).
} 
large point sources $\left(3.7 \mathrm{Gt} \mathrm{CO}_{2}\right)$. However, the proximity to major European storage sites in the UK and Norway may offer scope for an intensive use of CCS in the Netherlands. The Dutch government actively supports the deployment of CCS, e.g. by committing to contribute financially to the CCS demonstration in the Rotterdam area (Seebregts et al. 2010: 9).

The conservative estimate of Romania's total storage capacity is 9 Gt (Vangkilde-Pedersen, Allier, Anghel et al. 2009). Using data from Vangkilde-Pedersen, Kirk, Smith et al. (2009) on annual $\mathrm{CO}_{2}$ emissions from large point sources in Romania and applying them for forty years, the respective emissions over this period of time would amount to $2.7 \mathrm{Gt}$ (this method has also been applied in Höller and Viebahn 2011 to other countries) and thus the available storage capacity is rather high compared to the storage needs of Romanian large point sources. In the National Reform Programme released in 2011, the Romanian government committed to reduce GHG emissions (relatively to the 1990-level) by 20 percent until 2020, primarily by the use of CCS (http://www.zeroco2.no/projects/countries/romania).

There are still research gaps concerning the questions how CCS projects might be funded in prospective pioneer countries and how incentives for CCS investments can be improved. However, in the present study, we are not concerned with specific incentive schemes, but we consider two different scenarios presuming different market-maturity developments in the next two decades.

\section{Method}

In our study we assess the impact of deployment of power plants equipped with CCS on electricity production, on electricity import and exports as well as on the price of electricity at the spot-market by using a dispatched model. ${ }^{7}$ The model is based on data of EURELECTRIC and ENTSO-E for Europe 2030 (ENTSO-E 2011a, 2011b, 2012; EURELECTRIC 2010). 29 Countries in Europe and 40 different kinds of power plant techniques are taken in account. ${ }^{8}$ Using data on existing power plants stock and stock extensions provided by EURELECTRIC we draw inferences on power plant efficiencies and calculate power plant specific production cost by taking fuel prices into account (EURELECTRIC 2010, IEA 2011a). In accordance with ZEP, we assume that greenfield CCS-coal fired power plants will have efficiency losses of $8 \%$ points compared to a conventional coal fired power plant while retrofitted power plants will face efficiency losses up to $12 \%$ points (ZEP 2011, see Appendix Tab. A1)).

Based on information on the availability of the different types of power plants the optimal use of the power plant stocks is calculated. It is assumed that the power plant operators will use their power plants if the short-run marginal cost are lower than or equal to the price for electricity on the wholesale market. ${ }^{9}$ Electricity will be imported if the price in other countries is lower than the cost of using additional domestic power plants and if there are import capacities available (Rübbelke and Vögele 2013b).

\footnotetext{
${ }^{7}$ See, e.g., Göransson and Johnsson (2009) and Yongping et al. (2010) as examples for other case studies using load dispatch approaches.

${ }^{8}$ Information on the scenario-specific utilization rates of the different types of power plants considered in our study is displayed in Table A3 of the Appendix.

${ }^{9}$ Our assumptions about short-run marginal cost/efficiencies and resulting marginal cost is displayed in tables A2a,b in the Appendix.
} 
The impacts of changes in the power plant stock on revenues are assessed based on the national producer surpluses. Producer surplus reflects the aggregated sum of the differences between running cost and revenues from electricity sales.

Two scenarios have been selected for analyzing possible impact of deploying CCS in Europe (Figure 1). In the "Reference" scenario it is assumed that CCS power plants will not reach market maturity in the next 20 years in Europe. In the "CCS" scenario we anticipate that CCS power plants will be ready for the market in 2030. ${ }^{10}$ Information on the extent CCS will be deployed in each country is extracted from CCSA (2011), Bellona Environmental CCS Team (2011), Sund Energy (2010), Bellona Environmental CCS Team (2012b) and Energy Forum NL (2012).

In accordance with Table 1, we suppose that coal-fired CCS-power-plants will operate in Great Britain, the Netherlands, Poland as well as in Romania in 2030 and that in Great Britain and Norway gas fired power plant will be equipped with CCS (see Figure 1) till then.

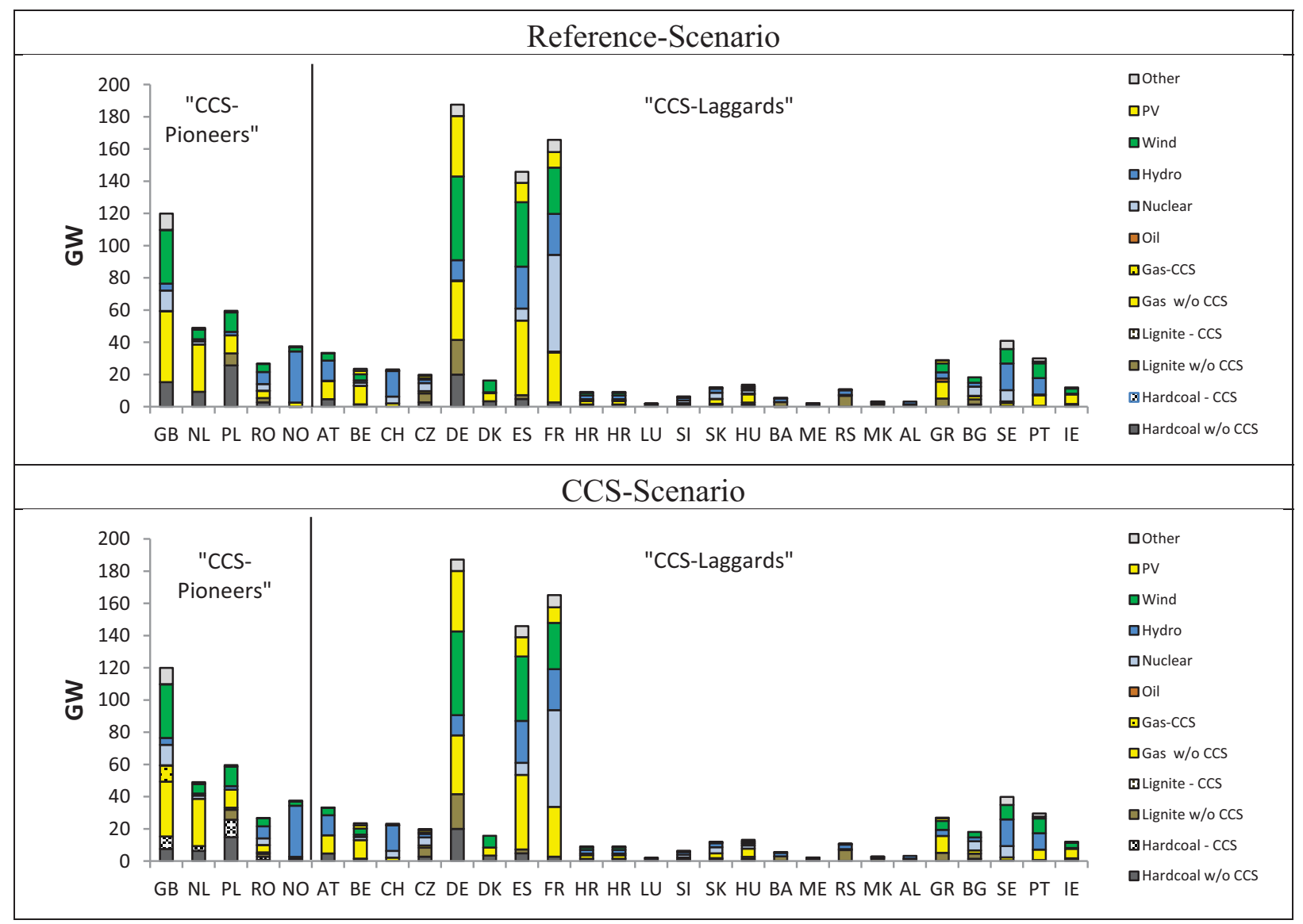

Remarks: AT: Austria, BE: Belgium, CH: Switzerland, CZ: Czech Republic, DE: Germany, DK: Denmark, ES: Spain, FR: France, GB: United Kingdom, HR: Croatia, IT: Italy, LU: Luxembourg, NL: Netherlands, PL: Poland, SI: Slovenia, SK: Slovakia, HU: Hungary, BA: Bosnia/Herzegovina, ME: Montenegro, RS: Serbia, MK: The former Yugoslav Republic of Macedonia, AL: Albania, GR: Greece, BG: Bulgaria, RO: Romania, SE: Sweden, NO: Norway, PT: Portugal, IE: Ireland

Figure 1: Installed Capacities in Europe in 2030

\footnotetext{
${ }^{10}$ European Parliament and Council (2009) assess that $15 \%$ of the $\mathrm{CO}_{2}$ reductions required in the EU in 2030 could be achieved by the implementation of CCS technologies.
} 
Information on the assumptions concerning installed CCS capacities is displayed in Table A4 of the Appendix.

\section{Results}

Coal-fired power plants equipped with CCS techniques have lower efficiencies and therefore higher fuel cost than conventional power plants. However, reductions in $\mathrm{CO}_{2}$ emissions result in lower cost for $\mathrm{CO}_{2-}$ certificates. Assuming a price for $\mathrm{CO}_{2}$-allowances of $30 \mathrm{Euro} / \mathrm{t} \mathrm{CO}_{2}$, the short-run marginal cost (including O\&M cost, fuel cost and penalty assumed for emitting $\mathrm{CO}_{2}$ ) of coal-fired CCS power plants will be lower than those of conventional coal power plants. ${ }^{11}$ Usually gas-fired power plants are the marginal power plants which determine the wholesale price. Consequently, advances in cost reductions in coal-fired power plants with CCS will increase producer (of electricity from coal-fired plants) surpluses in the corresponding country, given the wholesale price as determined by gas-fired power plants (for a discussion of the effects of cost reductions on both producer and consumer surpluses see Rübbelke and Vögele 2013a).

If gas-fired power plants are equipped with CCS, the overall short-run marginal cost will rise because small reductions in $\mathrm{CO}_{2}$-cost will be overcompensated by high increases in fuel cost. As mentioned above, in our CCS-scenario gas-fired CCS-power plants will be used in Great Britain and the Netherlands. In both countries the average price for electricity on the wholesale market will increase because these costly power plants will be the ones which determine the wholesale price (see Figure 2).

Increases in electricity (wholesale) prices affect particularly sectors with high specific electricity consumption. Examples are "production of iron and steel" or "production of aluminum". Regarding products of these sectors there is a high competition on the global market. Consequently these sectors as well as the supplying industry and other economic actors are not interested in increasing electricity prices."

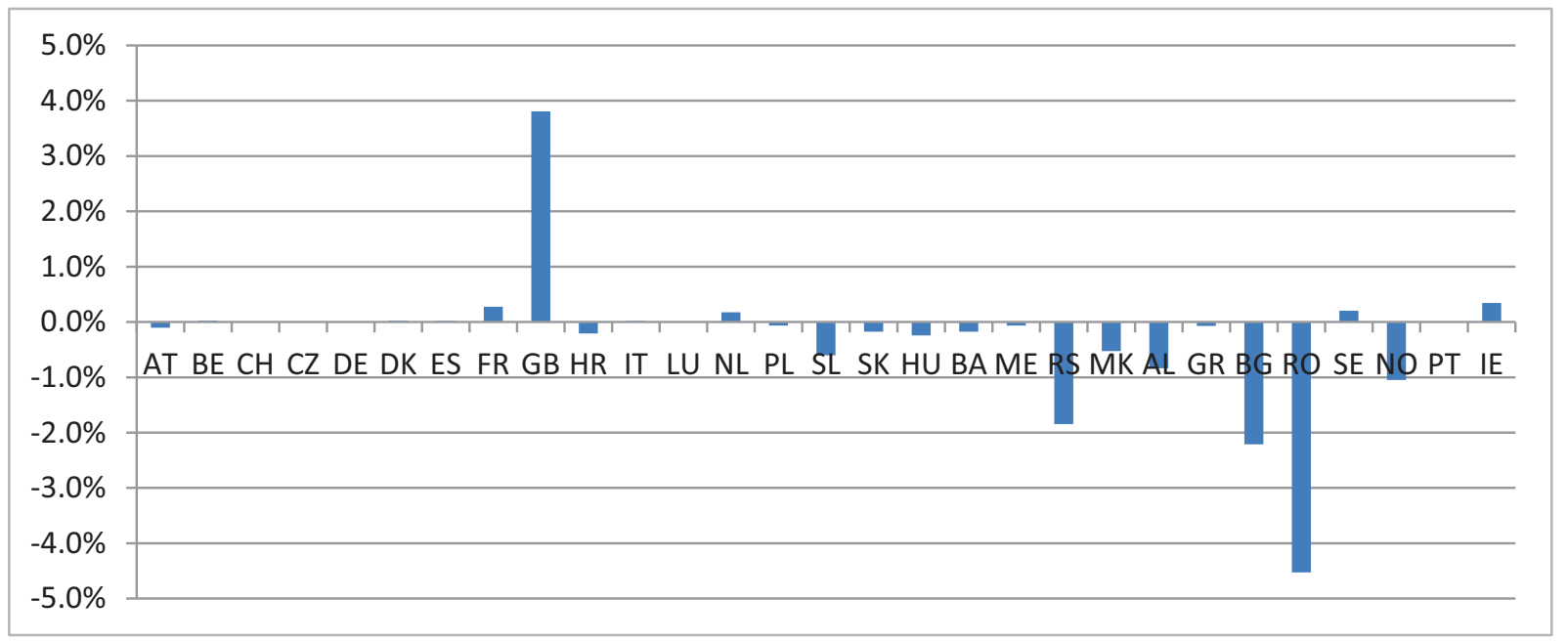

Figure 2: Changes in Wholesale Prices in 2030

\footnotetext{
${ }^{11}$ Presently (mid of 2013) the allowance price is only around 4 Euros/t $\mathrm{CO}_{2}$. Therefore, climate policy has to become more ambitious in order to induce a carbon dioxide price (per ton) of around 30 Euros.
} 


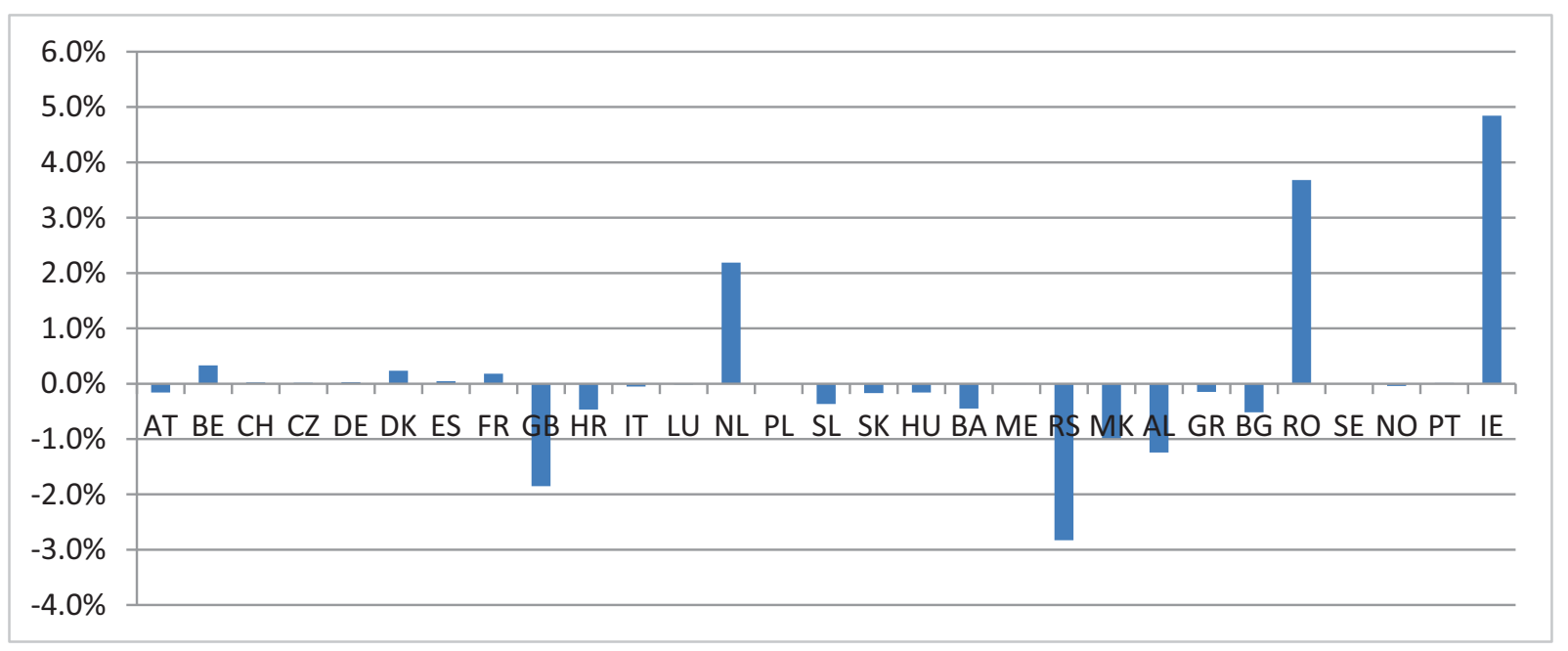

Figure 3: Changes in Electricity Production in 2030

An increase in the cost level fosters electricity imports by the affected countries and mitigates foreign countries' demand for electricity imports from those countries facing the rise in the cost level. We can observe that less electricity will be produced in Great Britain. In Romania the wholeprice will drop which results in a higher electricity demand and therefore in a higher electricity production (Error! Reference source not found.); see Rübbelke and Vögele (2013a,b) for a detailed description of the model used.

As a result of an increasing wholesale price in Great Britain caused by the use of gas-fired plants equipped with CCS and high fuel cost, the demand of France and Ireland for electricity from Great Britain will drop. On the other hand, more "cheap" electricity will be imported. As stated above, in Romania wholesale price will decrease because of relatively low running cost (incl. fuel cost and cost for $\mathrm{CO}_{2^{-}}$ allowances) of coal-fired power plants equipped with CCS. Cheap surplus electricity will be exported to the neighbor countries of Romania. There, the imported electricity will cut out domestic production. Error! Reference source not found. shows the changes in electricity imports per hour. While less electricity will be produced in the UK, British electricity imports will rise; imports will also strongly increase in Serbia. The changes in electricity imports of other countries are smaller.

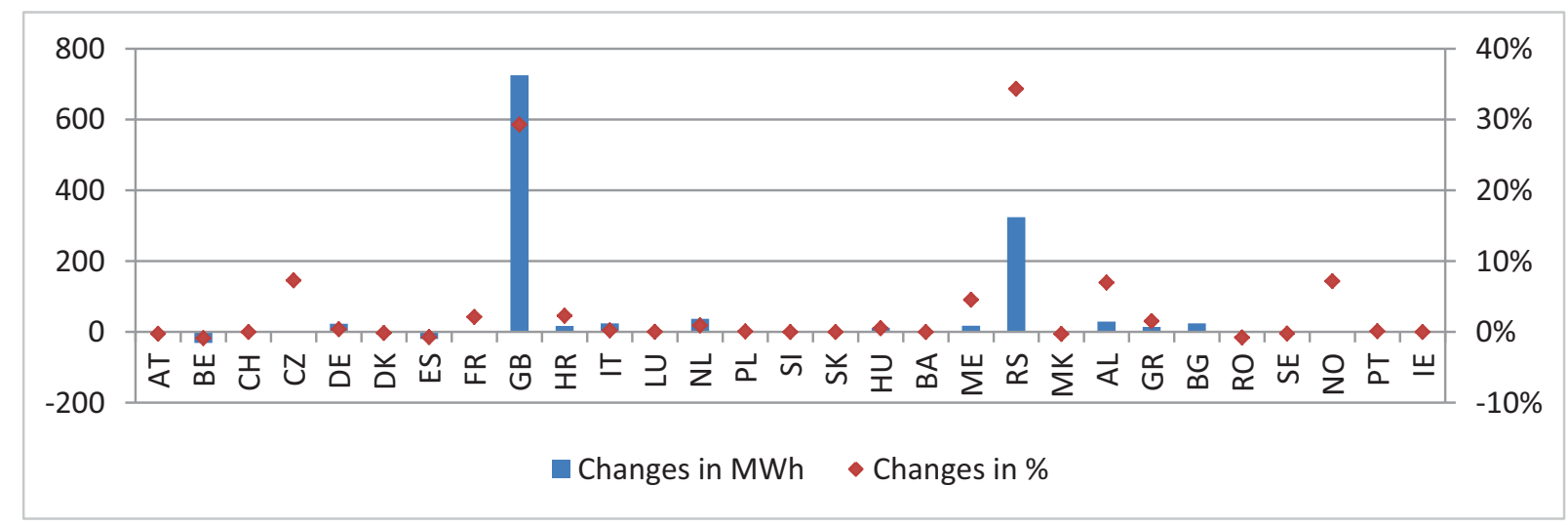

Figure 4: Changes in Electricity Imports per Hour (Average) in 2030 
Changes in prices in combination with changes in production ${ }^{12}$ and modifications in the merit-order curve result in changes in electricity producer surpluses (see Error! Reference source not found.). Such surpluses could be channeled towards the financing of CCS investment costs. High increases in producer surpluses can be expected for the three pioneer countries Poland, the Netherlands and Great Britain. These are countries where coal-fired power plants equipped with CCS will be used. Despite increases in electricity production, in Romania the producer surplus will decrease because of a lower electricity price level.

For an assessment of the economic advantages and disadvantages for investors of the use of CCS it is necessary to take a look at the overall cost effects: The investment costs of CCS power plants are significantly higher than the respective costs of conventional power plants (IEA 2011a; ZEP 2011). In Table 2 information on the additional (annualized) investment costs is provided. Taking these costs into account, the electricity suppliers in Great Britain, the Netherlands and Poland will still gain from the use of CCS. The overall result will remain negative for Norway and Romania. However, it has to be taken into account for the case of Romania that decreases in electricity prices and increases in production could have positive effects on the overall economy (e.g. increases in disposable income and employment).

The producer surplus reflects the sum of the revenues minus the running costs of power plants. Usually power plants with different running cost are in use. The wholesale price is determined by the power plant with highest running cost. Taking into account that on the spot markets only running costs count and that the running cost of coal- fired power plants with CCS are lower than the ones of conventional coal power plants (because of $\mathrm{CO}_{2}$ cost saving) with an increase use of such power plants the producer surplus will increase. However, if the wholesale price drops because more cheap power plant capacity is available the producer surplus decreases, too. For the assessment of the overall changes in producer surplus it is important to take the production into account, too: As the revenues are determined by the product of prices and production with increasing production caused by rising demand for electricity by foreign countries as well as higher wholesale prices resulting from using gas-fired power plants the producer surplus will rise. In Great Britain the wholesale price increases. Consequently the

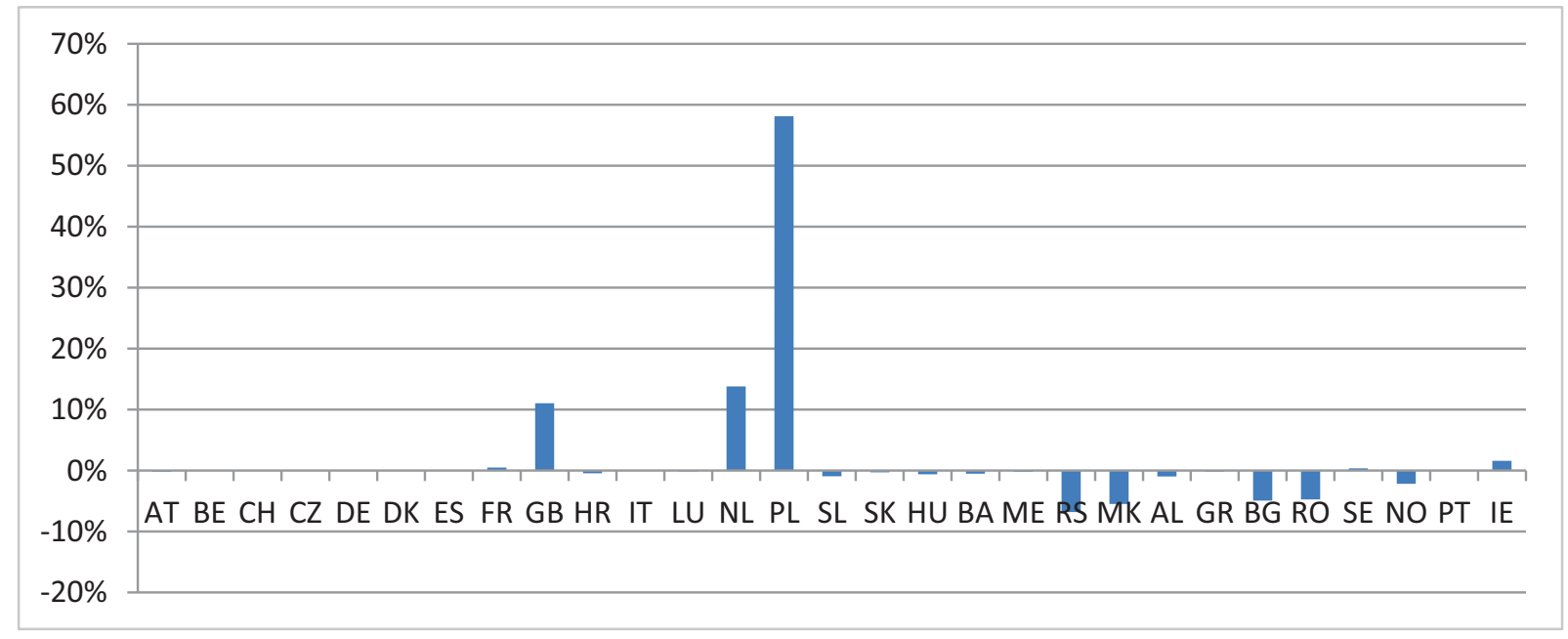

Figure 5: Changes in Electricity Producer Surplus in 2030

\footnotetext{
${ }^{12}$ See Appendix for information on the shares of different types of power plants on electricity supply.
} 
Table 2: Results (year 2030)

\begin{tabular}{|c|c|c|c|c|c|c|c|}
\hline & \multicolumn{5}{|c|}{ "CCS-Pioneers" } & \multirow{2}{*}{$\begin{array}{c}\text { "CCS- } \\
\text { Laggards" }\end{array}$} & \multirow{2}{*}{ Total } \\
\hline & GB & NL & PL & NO & RO & & \\
\hline $\begin{array}{l}\text { Changes in Annual Producer } \\
\text { Surplus (Mio. Euro) }\end{array}$ & $\begin{array}{c}1059 \\
(11.0 \%)\end{array}$ & $\begin{array}{c}268 \\
(13.8 \%)\end{array}$ & $\begin{array}{c}1109 \\
(58.1 \%)\end{array}$ & $\begin{array}{c}-36 \\
(-2.2 \%)\end{array}$ & $\begin{array}{c}-75 \\
(-4.7 \%)\end{array}$ & $\begin{array}{c}-38 \\
(-0.1 \%)\end{array}$ & $\begin{array}{l}2286 \\
(2.8 \%)\end{array}$ \\
\hline $\begin{array}{l}\text { Additional (annualized) } \\
\text { investment cost (Mio. Euro) }\end{array}$ & 803 & 136 & 545 & 46 & 142 & 0 & 1672 \\
\hline $\begin{array}{l}\text { Overall result (Surplus - Cost) } \\
\text { (in Mio. Euro) }\end{array}$ & 255 & 132 & 564 & -82 & -217 & -38 & 614 \\
\hline
\end{tabular}

Remarks: Calculations are based on data of IEA on the costs of power plants. (IEA, 2011a)

earning of the utilities rises, too. In Poland and the Netherlands the producer surplus grows because of changes in the slope of the merit-order curve caused by using coal-fired power plants with CCS which had lower $\mathrm{CO}_{2}$ costs than the conventional coal-fired power plant which are used in the reference scenario. In countries like Romania and Norway, the producer surpluses decrease due to lower revenues caused by drops in wholesale prices.

\section{Conclusions}

Time and tide wait for no man, but it seems that it does not always pay to be 'on time'. As our analysis shows, consequences of pioneering CCS activities tend to be rather heterogeneous. As a pioneer country, the UK will be confronted with a strong rise in wholesale electricity prices due to its ambitious deployment of gas-fired CCS power plants. Such an increase in wholesale prices might to some extent harm electricity consumers in the UK and it will be accompanied by a decline in domestic electricity production and a strong rise in electricity imports. In contrast, Romania will face a sharp decline in wholesale prices benefitting consumers and a strong growth in domestic electricity generation. Concerning electricity producer surpluses we also observe a mixed picture. Suppliers in Poland, the UK and the Netherlands tend to benefit, while suppliers in Norway and Romania will lose. This holds even when we take additional CCS investment costs into account.

Our results show also a diverse situation in laggard countries. Whole-sale prices in several laggard countries will decline due to the use of CCS in the pioneer countries, while they will rise in others (e.g. France). Electricity generation will increase in a number of laggard countries and even electricity suppliers in some laggard countries (e.g. Ireland) may raise their profits due to the CCS activities of the pioneers. Yet, total electricity producers' surplus in the group of laggard countries will decline, while the respective total surplus in the group of pioneer countries will strongly increase.

Thus, as we showed, the profitability of CCS deployment for individual countries does not crucially or only depend on whether a country acts as a pioneer or laggard. Both laggards and pioneers may observe beneficial effects. As the example of the UK shows, benefits of CCS deployment may be unevenly distributed within a country, abetting electricity suppliers while possibly disadvantaging 
consumers (due to higher electricity prices). Thus, governments aiming at favoring consumers might prefer to take the role of a laggard. Yet, as the examples of Romania and Norway demonstrate, this does not necessarily be the case as wholesale prices will also drop in these pioneer countries.

Finally, the results derived for specific countries have to be put into perspective as future developments concerning the deployment of CCS in individual countries are subject to high uncertainty. Presently, CCS is subject to strong criticism - inter alia - because may involve significant environmental risks (see, e.g. IPCC 2005, Wilson, Friedmann and Pollak 2007 and Halsband and Kurihara 2013, who address such risks). Against this background, the assumptions made in our analysis of effects of partial CCS deployment in Europe might be seen as rather 'optimistic' concerning the extent of future CCS deployment.

\section{Acknowledgements}

This paper was partly funded under the project "Strategic Challenges in International Climate and Energy Policy (CICEP)" sponsored by the Research Council of Norway.

\section{References}

Bellona Environmental CCS Team (2011). Insuring Energy Independence - A CCS Roadmap for Poland. Bellona Foundation, Krakow.

Bellona Environmental CCS Team (2012a) CCS_projects, http://bellona.org/ccs/ccs-projects.html, 15/10/2012.

Bellona Environmental CCS Team, (2012b). Our Future is Carbon Negative - A CCS Roadmap for Romania. Bellona Foundation, Krakow.

CCSA (2011) A Strategy for CCS in the UK and Beyond. The Carbon Capture \& Storage Association, London.

DECC (2012a) CCS Roadmap - Supporting Deployment of Carbon Capture and Storage in the UK, London.

DECC (2012b) Fuel Mix Disclosure Table, http://www.decc.gov.uk/en/content/cms/statistics/energy_stats/fuel_mix/fuel_mix.aspx.

EC (2013) Communication from the Commission to the European Parliament, the Council, the European Economic and Social Committee of the Regions on the Future of Carbon Capture and Storage in Europe, Brussels.

Energy Forum NL (2012) Optimized pathways to CO2 reduction in the Dutch context. http://www.gasterra.com, $10 / 12 / 2012$.

ENTSO-E (2011a) Data Portal CE - Production http://www.entsoe.eu, 12/12/2011.

ENTSO-E (2011b) NTC Values https://www.entsoe.eu/resources/ntc-values/ntc-matrix. 02/03/2011.

ENTSO-E (2012) Ten-Year Network Development Plan 2012 Project for Consultation, Brussels.

EURELECTRIC (2010) Power Statistics 2010 Edition, Brussels.

European Parliament and Council (2009) Directive 2009/31/EC of the European Parliament and of the Council of 23 April 2009 on the geological storage of carbon dioxide and amending Council Directive 85/337/EEC, European Parliament and Council Directives 2000/60/EC, 2001/80/EC, 2004/35/EC, 2006/12/EC, 2008/1/EC and Regulation (EC) No 1013/2006. Strasbourg.

Göransson, L. and Johnsson, F. (2009) Dispatch modeling of a regional power generation system - Integrating wind power, Renewable Energy, 34, 1040-1049. 
Gupta, J. (2010) A History of International Climate Change Policy, WIREs Climate Change, 1, 636-653.

Halsband, C. and Kurihara, H. (2013) Potential Acidification Impacts on Zooplankton in CCS Leakage Scenarios, Marine Pollution Bulletin, forthcoming.

Hey, C. (2010) The German Paradox: Climate Leader and Green Car Laggard, in: Oberthür, S. and Pallemaerts, M. (eds.), The New Climate Policies of the European Union: Internal Legislation and Climate Diplomacy, VUBPRESS Brussels University Press, Brussels, 211-230.

Höller, S. and Viebahn, P. (2011) Assessment of $\mathrm{CO}_{2}$ Storage Capacity in Geological Formations of Germany and Northern Europe, Energy Procedia, 4, 4897-4904.

IEA (2011a) World Energy Outlook - Investment Costs http://www.worldenergyoutlook.org/investments.asp, $07 / 02 / 2012$

IEA (2011b) World Energy Outlook 2011, OECD/IEA, Paris.

IPCC (2005) Carbon Dioxide Capture and Storage, B. Metz, O. Davidson, H. de Coninck, M. Loos and L. Meyer (eds.), Cambridge University Press, Cambridge.

Luderer, G., Bosetti, V., Jakob, M., Leimbach, M., Steckel, J.C., Waisman, H. and Edenhofer, O. (2012) The Economics of Decarbonizing the Energy System - Results and Insights from the RECIPE Model Intercomparison, Climatic Change, 114, 9-37.

OECD/IEA (2010) Energy and $\mathrm{CO}_{2}$ Emissions Scenarios of Poland, http://www.mg.gov.pl/files/upload/10460/ENERGY_AND_CO2_MAE.pdf.

Perino, G. and Requate, T. (2012) Does more stringent environmental regulation induce or reduce technology adoption? When the rate of technology adoption is inverted U-shaped, Journal of Environmental Economics and Management, 64, 456-467.

Requate, T. (2005) Timing and Commitment of Environmental Policy, Adoption of New Technology, and Repercussions on R\&D, Environmental and Resource Economics, 31, 175-199.

Rübbelke, D. and Vögele, S. (2013a) Effects of Carbon Dioxide Capture and Storage in Germany on European Electricity Exchange and Welfare, Energy Policy, 59, 582-588.

Rübbelke, D. and Vögele, S. (2013b) Short-term Distributional Consequences of Climate Change Impacts on the Power Sector: Who Gains and Who Loses?, Climatic Change, 116, 191-206.

Seebregts, A.J., Groenenberg, H., Boot, P.A. and Snoep, H.J.M. (2010) Policy Instruments for Advancing CCS in Dutch Power Generation, ECN Report No. ECN-E--10-032, Petten.

Shackley, S., Waterman, H., Godfroij, P., Reiner, D., Anderson, J., Draxlbauer, K. et al. (2007) Stakeholder Perceptions of $\mathrm{CO}_{2}$ Capture and Storage in Europe: Results from the EU-funded ACCSEPT Survey, Deliverable D3.1 from ACCSEPT - Main Report, Høvik.

Shackley, S., Reiner, D., Upham, P., de Coninck, H., Sigurthorsson, G. and Anderson, J. (2009) The Acceptability of $\mathrm{CO}_{2}$ Capture and Storage (CCS) in Europe: An Assessment of the Key Determining Factors - Part 2. The Social Acceptability of CCS and the Wider Impacts and Repercussions of its Implementation, International Journal of Greenhouse Gas Control, 3, 344-356.

Sund Energy, 2010. CCS in the Nordic countries in a renewable/climate neutral future (2050), Oslo.

Szulczewski, M.L., MacMinn, C.W., Herzog, H.J. and Juanes, R. (2012) Lifetime of Carbon Capture and Storage as a Climate-Change Mitigation Technology, Proceedings of the National Academy of Sciences of the United States of America (PNAS), 109, 5185-5189. 
Vangkilde-Pedersen, T., Allier, D., Anghel, S., Anthonsen, K.L., Bossie-Codreanu, D., Car, M. et al. (2009) EU GeoCapacity - Assessing European Capacity for Geological Storage of Carbon Dioxide, WP2 Report, GEUS, Copenhagen.

Vangkilde-Pedersen, T., Kirk, K., Smith, N., Maurand, N., Wójcicki, A., Neele, F. et al. (2009) EU GeoCapacity Assessing European Capacity for Geological Storage of Carbon Dioxide, Final Report, GEUS, Copenhagen.

Van Soest, D. (2005) The impact of environmental policy instruments on the timing of adoption of energy-saving technologies, Resource and Energy Economics, 27, 235-247.

Wilson, E.J., Friedmann, S.J. and Pollak, M.F. (2007) Research for Deployment: Incorporating Risk, Regulation, and Liability for Carbon Capture and Sequestration, Environmental Science and Technology, 41, 5945-5952.

World Bank (2011) Transition to a Low-Emissions Economy in Poland, Washington D.C.

World Coal Association (2012) Coal Facts 2012: Based on 2011 IEA and BP data published in 2012, London.

Yongping, Y., Rongrong, Z., Liqiang, D., Masek, O. and Oakey, J. (2010) Study on Multi-Objective Optimization of Load Dispatch Including Renewable Energy and CCS Technologies, International Journal of Energy Research, 34, 702-715.

ZEP- Zero Emissions platform (2011) The Costs of $\mathrm{CO}_{2}$ Capture, Brussels. 


\section{Supplementary Material}

Table A1: Assumed Fuel Prices

\begin{tabular}{|l|r|r|}
\hline Hard Coal & 2.9 & Euro/GJ \\
\hline Lignite & 1.5 & Euro/GJ \\
\hline Natural Gas & 8.7 & Euro/GJ \\
Oil & 15.0 & Euro/GJ \\
\hline Source: own calculations based on IEA $(2011 \mathrm{~b})$ \\
\hline
\end{tabular}

Source: own calculations based on IEA (2011b)

Table A2a: Assumptions on short-run marginal cost/efficiencies and resulting marginal cost (2030)

\begin{tabular}{l|c|c|c} 
& $\begin{array}{c}\text { O\&M costs } \\
\text { (without fuel } \\
\text { cost) } \\
\text { Euro/MWh }\end{array}$ & $\begin{array}{c}\text { Efficiency* } \\
\text { (gross) }\end{array}$ & $\begin{array}{c}\text { Resulting short run marginal cost } \\
\text { (incl. fuel cost fuel costs and penalty } \\
\text { assumed for emitting } \text { CO }_{2} \text { ) }\end{array}$ \\
\hline Hard Coal w/o CCS & 1 & $38-49$ & Euro/MWh \\
Hard Coal w CCS & 3 & $35-41$ & $44-56$ \\
Lignite w/o CCS & 1 & $36-47$ & $33-38$ \\
Lignite with CCS & 3 & $33-39$ & $39-50$ \\
Natural Gas w/o CCS & 0 & $46-66$ & $22-26$ \\
Natural Gas with CCS & 1 & $50-55$ & $57-81$ \\
Nuclear & 5 & 33 & $64-68$ \\
Oil & 5 & $34-43$ & 15.9 \\
Renewables & $0-1$ & 100 & $151-175$ \\
\hline
\end{tabular}

Remarks: * Values depend on vintage structure of power plant

Sources: (IEA 2011a; ZEP 2011), own calculations based on (EURELECTRIC 2010) 
Table A2b: Short-run marginal cost/efficiencies and resulting marginal cost (2010)

\begin{tabular}{l|c|c|c} 
& $\begin{array}{c}\text { O\&M costs } \\
\text { (without fuel } \\
\text { cost) } \\
\text { Euro/MWh }\end{array}$ & $\begin{array}{c}\text { Efficiency* } \\
\text { (gross) }\end{array}$ & $\begin{array}{c}\text { Resulting short run marginal cost } \\
\text { (incl. fuel cost fuel costs and penalty } \\
\text { assumed for emitting CO } \text { CO }_{2}\end{array}$ \\
\hline Hard Coal w/o CCS & 1 & $32-45$ & Euro/MWh \\
Hard Coal w CCS & $\mathrm{n} / \mathrm{a}$ & $\mathrm{n} / \mathrm{a}$ & $32-43$ \\
Lignite w/o CCS & 1 & $31-43$ & $\mathrm{n} / \mathrm{a}$ \\
Lignite with CCS & $\mathrm{n} / \mathrm{a}$ & $\mathrm{n} / \mathrm{a}$ & $25-34$ \\
Natural Gas w/o CCS & 0 & $36-59$ & $\mathrm{n} / \mathrm{a}$ \\
Natural Gas with CCS & $\mathrm{n} / \mathrm{a}$ & $\mathrm{n} / \mathrm{a}$ & $52-85$ \\
Nuclear & 5 & 33 & $\mathrm{n} / \mathrm{a}$ \\
Oil & 5 & $31-37$ & 16 \\
Renewables & $0-1$ & 100 & $114-135$ \\
Remarks: * Values depend on vintage structure of power plant \\
Sources: (IEA 2011a; ZEP 2011), own calculations based on (EURELECTRIC 2010)
\end{tabular}

Table A3: Utilization by Power Plant Technology

\begin{tabular}{|c|c|c|c|c|c|c|c|c|c|c|}
\hline & $\begin{array}{l}\text { GB } \\
\text { REF }\end{array}$ & CCS & $\begin{array}{l}\text { NL } \\
\text { REF }\end{array}$ & CCS & $\begin{array}{l}\mathrm{PL} \\
\mathrm{REF}\end{array}$ & CCS & $\begin{array}{l}\mathrm{NO} \\
\mathrm{REF}\end{array}$ & CCS & $\begin{array}{l}\text { RO } \\
\text { REF }\end{array}$ & $\mathrm{CCS}$ \\
\hline $\begin{array}{l}\text { Hard Coal } \\
\text { w/o CCS }\end{array}$ & $82 \%$ & $78 \%$ & $83 \%$ & $82 \%$ & $66 \%$ & $51 \%$ & $16 \%$ & $16 \%$ & $4 \%$ & $0 \%$ \\
\hline $\begin{array}{l}\text { Hard Coal w } \\
\text { CCS }\end{array}$ & & $85 \%$ & & $85 \%$ & & $85 \%$ & & & & $18 \%$ \\
\hline $\begin{array}{l}\text { Lignite w/o } \\
\text { CCS }\end{array}$ & $0 \%$ & $0 \%$ & $0 \%$ & $0 \%$ & $70 \%$ & $66 \%$ & $0 \%$ & $0 \%$ & $10 \%$ & $1 \%$ \\
\hline $\begin{array}{l}\text { Lignite with } \\
\text { CCS }\end{array}$ & & & & & & $85 \%$ & & & & $43 \%$ \\
\hline $\begin{array}{l}\text { Natural Gas } \\
\text { w/o CCS }\end{array}$ & $21 \%$ & $21 \%$ & $16 \%$ & $17 \%$ & $1 \%$ & $1 \%$ & $5 \%$ & $0 \%$ & $0 \%$ & $0 \%$ \\
\hline $\begin{array}{l}\text { Natural Gas } \\
\text { with CCS }\end{array}$ & & $13 \%$ & & & & & & $5 \%$ & & \\
\hline Oil & $0 \%$ & $0 \%$ & $0 \%$ & $0 \%$ & $0 \%$ & $0 \%$ & $0 \%$ & $0 \%$ & $0 \%$ & $0 \%$ \\
\hline Nuclear & $85 \%$ & $85 \%$ & $85 \%$ & $85 \%$ & $0 \%$ & $0 \%$ & $0 \%$ & $0 \%$ & $78 \%$ & $78 \%$ \\
\hline Hydro & $85 \%$ & $85 \%$ & $0 \%$ & $0 \%$ & $85 \%$ & $85 \%$ & $71 \%$ & $71 \%$ & $85 \%$ & $85 \%$ \\
\hline Wind & $16 \%$ & $16 \%$ & $16 \%$ & $16 \%$ & $16 \%$ & $16 \%$ & $16 \%$ & $16 \%$ & $16 \%$ & $16 \%$ \\
\hline PV & $10 \%$ & $10 \%$ & $10 \%$ & $10 \%$ & $0 \%$ & $0 \%$ & $0 \%$ & $0 \%$ & $0 \%$ & $0 \%$ \\
\hline OTHER & $2 \%$ & $2 \%$ & $2 \%$ & $2 \%$ & $1 \%$ & $1 \%$ & $0 \%$ & $0 \%$ & $0 \%$ & $0 \%$ \\
\hline Total & $33 \%$ & $33 \%$ & $31 \%$ & $32 \%$ & $42 \%$ & $42 \%$ & $57 \%$ & $57 \%$ & $37 \%$ & $38 \%$ \\
\hline
\end{tabular}

Source: Own calculations 
Table A4: Assumed CCS-Capacity $(G W)$

$\begin{array}{lccccc} & \text { GB } & \text { NL } & \text { PL } & \text { RO } & \text { NO } \\ \text { Hard Coal - CCS } & 7.8 & 3.0 & 10.9 & 1.9 & 0.0 \\ \text { Lignite - CCS } & 0.0 & 0.0 & 1.3 & 0.9 & 0.0 \\ \text { Gas-CCS } & 10.0 & 0.0 & 0.0 & 0.0 & 1.4\end{array}$

Source: Own calculation

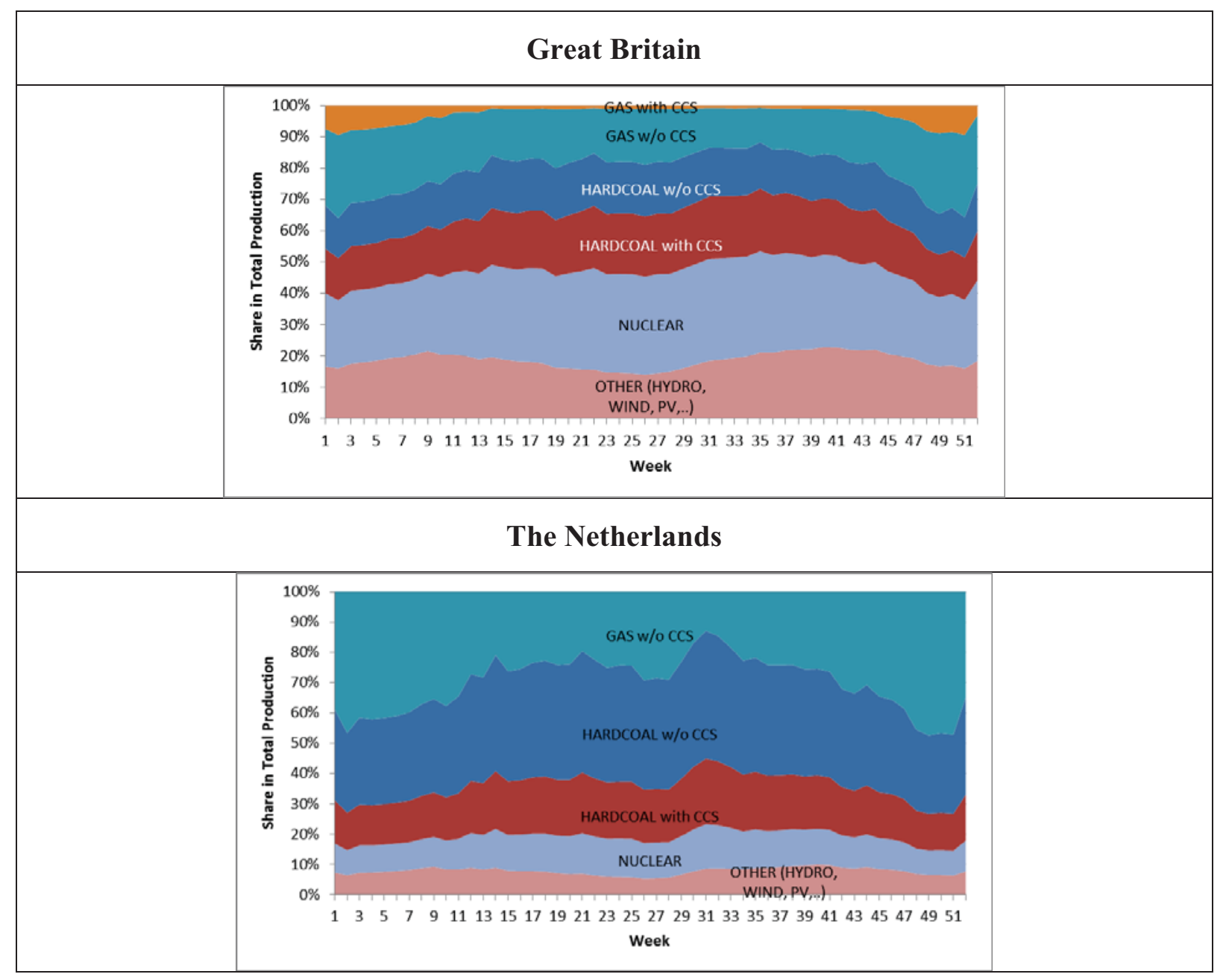

Figure Ala: CCS-Pioneers - Structure of Electricity Supply (weekly level) 


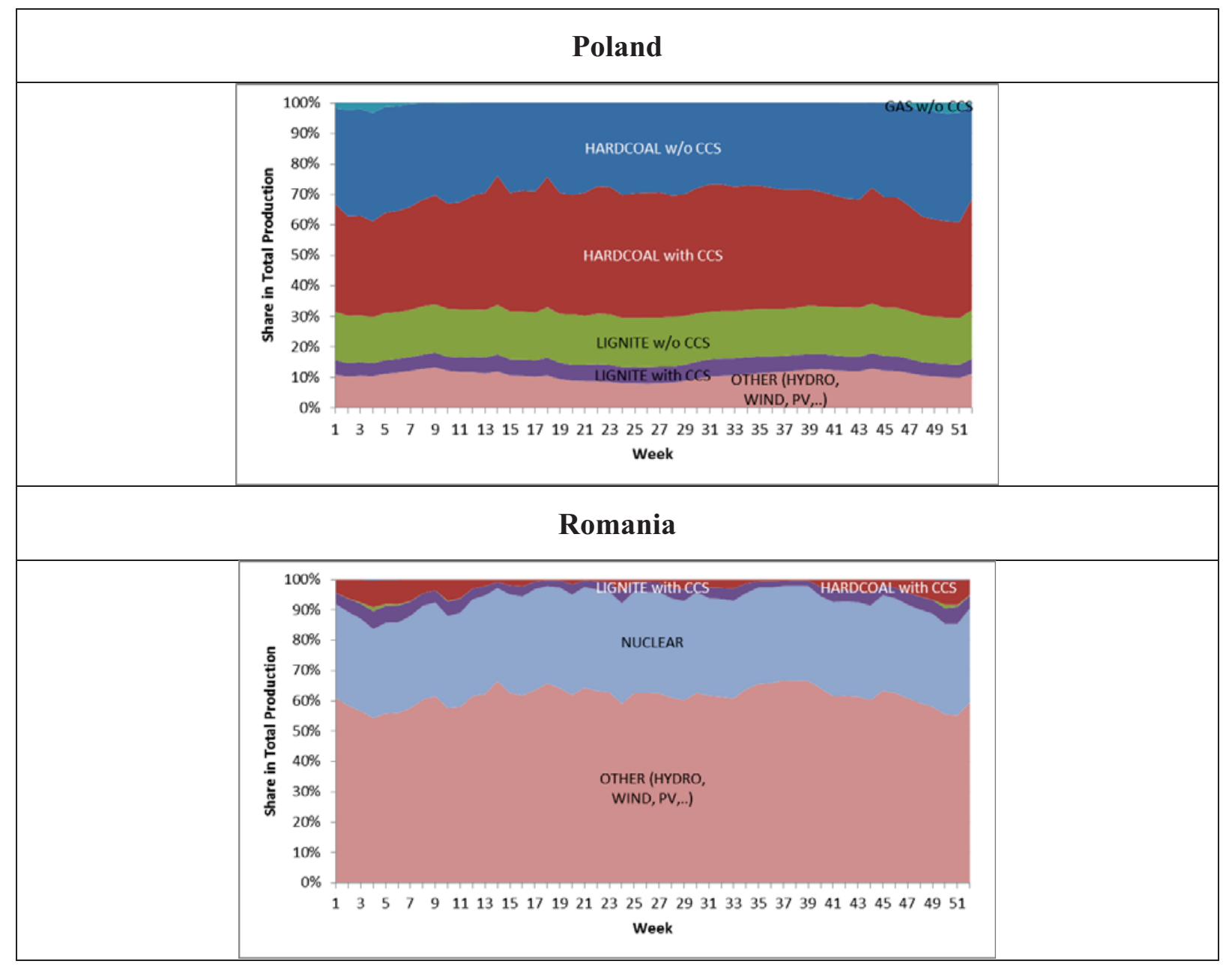

Figure A1b: CCS-Pioneers - Structure of Electricity Supply (weekly level) 


\section{BC3 WORKING PAPER SERIES}

\section{Basque Centre for Climate Change (BC3), Bilbao, Spain}

The BC3 Working Paper Series is available on the internet at the following addresses:

http://www.bc3research.org/lits publications.html

http://ideas.repec.org/s/bcc/wpaper.html

BC3 Working Papers available:

$2012-13$

2012-14

2013-01

2013-02

2013-03

2013-04

2013-05

2013-06

2013-07

2013-08

2013-09

2013-10

2013-11

2013-12

2013-13

Helen Ding, Anil Markandya and Paulo A.L.D. Nunes: The Economic Impacts of Biodiversity Policy for Improving the Climate Regulating Services Provided by EU Natura 2000 Habitats

Martin-Ortega, J. E. Ojea and C. Roux. Payments for Water Ecosystem Services in Latin America: Evidence from Reported Experience.

Samuel Bobbino, Héctor Galván and Mikel González-Eguino: Budget-Neutral Financing to Unlock Energy Savings Potential: An Analysis of the ESCO Model in Barcelona

Agustin del Prado, Karlos Mas, Guillermo Pardo and Patricia Gallejones: Development of a new modelling framework to estimate the C footprint from Basque dairy farms

Roger Fouquet: Long Run Demand for Energy Services: the Role of Economic and Technological Development

David Heres, Steffen Kallbekken and Ibon Galarraga: Understanding Public Support for ExternalityCorrecting Taxes and Subsidies: A Lab Experiment

Ibon Galarraga, Luis María Abadie and Alberto Ansuategi: Economic Efficiency, Environmental Effectiveness and Political Feasibility of Energy Efficiency Rebates: the Case of the Spanish Energy Efficiency "Renove" Plan.

Alexander Golub, Oleg Lugovoy, Anil Markandya, Ramon Arigoni Ortiz and James Wang: Regional IAM: Analysis of Risk-Adjusted Costs and Benefits of Climate Policies

Luis M. Abadie, Ibon Galarraga and Dirk Rübbelke: Evaluation of Two Alternative Carbon Capture and Storage Technologies: A Stochastic Model

Ibon Galarraga and Josu Lucas: Economic Evaluation of Energy Efficiency Labelling in Domestic Appliances: the Spanish Market

Daniel Nachtigall and Dirk Rübbelke: The Green Paradox and Learning-by-doing in the Renewable Energy Sector

Elisa Sainz de Murieta and Aline Chiabai: Climate change impacts on the water services in Costa Rica: a production function for the hydroenergy sector

Marta Olazabal and Unai Pascual: Identifying social determinants of urban low carbon transitions: the case of energy transition in Bilbao, Basque Country

Stefano Balbi, Carlo Giupponi, Roland Olschewski and Vahid Mojtahed: The economics of hydrometeorological disasters: approaching the estimation of the total costs

Dirk Rübbelke and Stefan Vögele: Time and tide wait for no man: pioneers and laggards in the deployment of CCS 